Artikel Riset

DOI : 10.33751 /jf.v9i2.1610
Fitofarmaka Jurnal Ilmiah Farmasi

Vol.9, No.2, Desember 2019 : 109-122

p-ISSN : 2087-9164 e-ISSN : 2622-755X

\title{
KAJIAN RASIONALITAS RESEP ANTIBIOTIKA CEPHALOSPORIN \\ UNTUK PROFILAKSIS BEDAH DI RUMAH SAKIT DR. H. MARZOEKI MAHDI BOGOR PERIODE DESEMBER 2011 - NOVEMBER 2012
}

\author{
Nyayu Siti Aminah Lily Elfrieda \\ Program Studi Farmasi FMIPA Universitas Pakuan Bogor, PO Box 452 Bogor 16143 \\ West Java, Indonesia \\ E-mail: lily_elfrieda@yahoo.co.id
}

Diterima : 30 Juli 2019

Direvisi : 17 Oktober 2019

Disetujui : 19 November 2019

\begin{abstract}
ABSTRAK
Pelayanan kefarmasian yang baik akan memberikan dampak positif pada peningkatan mutu pelayanan kesehatan, penurunan biaya kesehatan, dan peningkatan perilaku rasional dari seluruh tenaga kesehatan, pasien, keluarga pasien, dan masyarakat. Pelayanan kefarmasian ini mencakup pelayanan kepada seluruh pasien yang dirawat di rumah sakit maupun pasien yang akan pulang karena pasien-pasien ini memiliki peluang besar terhadap infeksi nosokomial atau hospital acquired infection (HAI). Salah satu penyebab infeksi nosocomial adalah penggunaan antibiotika yang tidak rasional. Kejadian infeksi ini meningkatkan angka kesakitan (morbiditas) dan kematian (mortalitas), lamanya perawatan, dan meningkatkan biaya pengobatan bagi pasien. Hal tersebut dapat diturunkan atau dihilangkan dengan cara mencegah infeksi yang terjadi di rumah sakit. Salah satu cara untuk menurunkan kejadian infeksi khususnya di tempat pembedahan adalah dengan pemberian antibiotika profilaksis. Penelitian ini bertujuan untuk menilai rasionalitas penggunaan antibiotika cephalosporin untuk profilaksis bedah. Penggunaan antibiotika cephalosporin biasanya dipilih untuk profilaksis infeksi dalam tindakan bedah. Namun, pada kenyataannya beberapa bakteri resisten terhadap aktivitas antibiotika ini karena praktek penggunaannya yang tidak rasional. Penggunaan antibiotika cephalosporin secara rasional diharapkan dapat memberikan dampak positif pada pasien. Penelitian ini adalah deskriptif observasional analitis yang dilakukan secara retrospektif. Data penggunaan antibiotika sefalosporin diambil pada pasien yang sudah pulang pada periode Desember 2011 hingga November 2012. Populasi penelitian ini adalah pasien yang menjalani tindakan bedah di RS Dr. H. Marzoeki Mahdi Bogor yang menerima resep antibiotika cephalosporin. Studi ini menemukan bahwa rasionalitas antibiotik dalam catatan medis pasien yang menjalani tindakan bedah di RS Dr. H. Marzoeki Mahdi Bogor menunjukkan bahwa sebagian besar antibiotika cephalosporin digunakan termasuk dalam kategori I yaitu antibiotika digunakan secara rasional oleh dokter. Hanya sebagian kecil yang memenuhi penggunaan antibiotika cephalosporin yang termasuk dalam kategori VI dikarenakan data tidak lengkap.
\end{abstract}

Kata kunci: Cephalosporin, Antibiotika, Rasionalitas antibiotika, Metode Gyssens, 


\title{
RATIONALITY STUDY OF CEPHALOSPORIN ANTIBIOTIC RECIPES FOR PROPHYLAXIS SURGERY IN HOSPITAL DR. H. MARZOEKI MAHDI BOGOR DECEMBER 2011 - NOVEMBER 2012 PERIOD
}

\begin{abstract}
Good pharmaceutical services will improve the quality of health services, reducing health costs, and improving the rational behavior of all health workers, patients, patients' families, and the community. This pharmaceutical service includes services for all patients who are treated in hospitals and patients who will go home, because patients who are treated in hospitals and patients who return run the risk of becoming infected with nosocomial infection or hospital acquired infection (HAI). This is partly due to the irrational use of antibiotics. Therefore, the role of health practitioners in the rational use of antibiotics is very important. The incidence of this infection increases morbidity and mortality, duration of treatment, and increases the cost of treatment for patients. This can be reduced or eliminated by preventing infections that occur in hospitals. One way to reduce the incidence of infection, especially at the surgical site, is prophylactic antibiotics. This study aims to assess the rationality of the use of cephalosporin antibiotics for surgical prophylaxis. The use of cephalosporin antibiotics is usually chosen for prophylactic infections in surgical procedures. However, in reality some bacteria are resistant to antibiotic activity because of their irrational use practices. The Rational use of cephalosporin antibiotics is expected to have a positive impact on patients. This research is a descriptive analytical observational study that was conducted retrospectively. Data on the use of cephalosporin antibiotics were taken from patients who had returned home within the period of this research. This research was conducted from December 2011 to November 2012. The population was patients who underwent surgery at Dr. Hospital. H. Marzoeki Mahdi, Bogor who received cephalosporin antibiotic prescriptions. This study argues that the rationality of antibiotics in the medical records of patients who underwent surgery showed that most of the cephalosporin antibiotic used to fell under the category $\mathrm{I}$, which is the antibiotics that were used rationally by doctors. Only a small proportion of those that met the use of the cephalosporin antibiotic that fell under the category VI due to incomplete data.
\end{abstract}

Keywords: Cephalosporin, Antibiotics, Gyssens method, Rational use of antibiotics

\section{PENDAHULUAN}

Keberadaan pelayanan farmasi yang baik akan memberikan dampak yang baik pada peningkatan mutu pelayanan kesehatan, penurunan biaya kesehatan, dan peningkatan perilaku yang rasional dari seluruh tenaga kesehatan, pasien, keluarga pasien, dan masyarakat. Pelayanan kefarmasian ini mencakup pelayanan kepada seluruh pasien yang dirawat di rumah sakit maupun pasien yang akan pulang, karena pasien yang dirawat di rumah sakit maupun pasien yang pulang memiliki peluang yang besar terhadap infeksi nosokomial atau hospital acquired infection (HAI). Menurut Linda (2004), dampak infeksi nosokomial menambah ketidakberdayaan fungsional, tekanan emosional, dan kadang-kadang pada beberapa kasus akan menyebabkan kondisi kecacatan sehingga menurunkan kualitas hidup Keadaan ini salah satunya 
disebabkan karena penggunaan antibiotika yang tidak rasional, oleh karena itu peran praktisi kesehatan dalam pemakaian antibiotik yang rasional sangatlah besar. Kejadian infeksi ini meningkatkan angka kesakitan (morbiditas) dan kematian (mortalitas), lamanya perawatan, dan meningkatkan biaya pengobatan bagi pasien. Hal tersebut dapat diturunkan atau dihilangkan dengan cara mencegah infeksi yang terjadi di rumah sakit. Salah satu cara untuk menurunkan kejadian infeksi khususnya di tempat pembedahan adalah dengan pemberian antibiotika profilaksis (Dellinger, 1994). Penggunaan antibiotika cephalosporin biasanya dipilih untuk profilaksis infeksi dalam tindakan bedah. Namun, pada kenyataannya beberapa bakteri resisten terhadap aktivitas antibiotika ini karena praktek penggunaannya yang tidak rasional. Penggunaan antibiotika cephalosporin secara rasional diharapkan dapat memberikan dampak positif pada pasien. Tindakan pembedahan merupakan salah satu sumber penyebab kejadian infeksi di rumah sakit, yaitu sebesar 23\%. Pada pasien bedah colorectal, kejadian infeksi ditemukan pada $40 \%$ pasien yang tidak mendapatkan antibiotika profilaksis, sedangkan pada pasien yang mendapatkan antibiotika profilaksis, kejadian infeksi ditemukan sebesar $11 \%$. Pada tahun 1993 diperkirakan infeksi yang didapat di rumah sakit terjadi pada pasien bedah di Inggris menyebabkan peningkatan biaya pengobatan lebih dari 170 juta pounds (Siregar, 2005).

Menurut Djoko Widodo (2006), penggunaan antibiotika pada pasien rawat inap mencapai 23-28\%. Dari persentase tersebut, $20-65 \%$ penggunaannya dianggap tidak tepat. Penelitian yang dilakukan oleh AMRIN didapatkan hasil sebesar $84 \%$ pasien rawat inap di RSUP
Kariadi Semarang yang mendapatkan terapi antibiotika, sedangkan pada bangsal rawat inap Ilmu Penyakit Dalam, pengunaan antibiotika mencapai $67 \%$.

Salah satu antibiotika yang menjadi pilihan dalam penanganan kejadian infeksi dan profilaksis bedah di RS Dr. H. Marzoeki Mahdi Bogor, khususnya di poliklinik bedah adalah antibiotika cephalosporin. Hal ini dikarenakan antibiotika cephalosporin merupakan antibiotika yang paling aman dan memiliki banyak pilihan obat disesuaikan dengan kebutuhan di lapangan serta memiliki potensi antibakteri yang besar. Disamping itu, RS Dr. H. Marzoeki Mahdi merupakan rumah sakit pemerintah yang menitikberatkan pengobatannya pada pasien askes, jamkesmas, dan jamkesda, sehingga antibiotika yang direkomendasikan adalah antibiotika cephalosporin.. Walaupun begitu, penggunaan antibiotika cephalosporin perlu mendapat perhatian khusus dari kalangan praktisi medis karena beberapa bakteri dalam prakteknya mengalami resisten terhadap aktivitasnya dikarenakan penggunaan antibiotika yang tidak rasional. Hal ini mendorong peneliti untuk meneliti penggunaan antibiotika cephalosporin yang rasional pada pasien rawat inap poliklinik bedah RS Dr. $\mathrm{H}$. Marzoeki Mahdi Bogor selama tahun 2011-2012 dengan didasarkan pada kriteria Gyssens dan memastikan pasien di RS Dr. H. Marzoeki Mahdi menerima pengobatan yang sesuai dengan kebutuhan klinis dalam dosis yang sesuai dengan kebutuhan individu dalam jangka waktu tertentu dengan biaya terapi yang seminimal mungkin.

\section{Waktu dan Tempat Penelitian}

Penelitian dilakukan pada bulan Oktober 2012 sampai dengan Desember 
2012 dengan mengambil data pasien yang dirawat di RS Dr. H. Marzoeki Mahdi Bogor selama periode Desember 2011 sampai dengan November 2012.

\section{Populasi dan Sampel}

Populasi penelitian ini adalah resep yang mengandung antibiotika cephalosporin yang ditujukan untuk pasien semua usia yang dirawat inap di poliklinik bedah RS Dr. H. Marzoeki Mahdi Bogor. Tehnik pengambilan sampel menggunakan metode simple random sampling untuk mendapatkan 100 rekam medik di mana populasi yang diambil berjumlah 316 pasien rawat inap poli bedah RS Dr. H. Marzoeki Mahdi Bogor. Jumlah sampel yang diambil ditetapkan berdasarkan cara penentuan ukuran sampel menurut rumus Slovin (Riduwan, 2012) dengan tingkat kesalahan 5\%, yaitu: $\mathrm{N}=\mathrm{n} / \mathrm{N}(\mathrm{d})^{2}+1$, dimana $\mathrm{n}=$ sampel; $\mathrm{N}=$ populasi; dan $\mathrm{d}=$ nilai presisi $95 \%=0,05$.

\section{Kriteria Inklusi dan Eksklusi}

Kriteria inklusi dalam penelitian adalah resep yang mengandung antibiotika cephalosporin dari pasien rawat inap poliklinik bedah RS Dr. H. Marzoeki Mahdi Bogor, resep yang mengandung kombinasi minimal dua antibiotika, resep yang mencantumkan dosis dan aturan pakai, resep yang mencantumkan nama dan nomor rekam medik pasien, pasien laki-laki dan perempuan, semua usia, dan semua kasus bedah.

Kriteria eksklusinya adalah resep untuk pasien pulang, resep hanya mengandung kombinasi antibiotika cephalosporin dengan satu atau lebih obat dengan penggunaan selain oral dan parenteral, resep dengan aturan pakai s.i.m.m (signa immanu medicine= dipakaikan oleh dokter), pada rekam medik tidak ada data usia pasien, pasien dengan angka kreatinin di atas normal, dan tidak ada data jenis kelamin.

\section{Teknik Pengumpulan Data}

Data dikumpulkan melalui pengambilan resep dari Instalasi Farmasi Rumah Sakit Dr. H. Marzoeki Mahdi depo rawat inap poliklinik bedah. Dihitung jumlah seluruh resep baik yang mengandung antibiotika cephalosporin maupun yang tidak. Resep yang mengandung cephalosporin dipisahkan dan dicatat. Resep tersebut ditetapkan sebagai populasi penelitian. Jumlah populasi dihitung, kemudian ditetapkan jumlah sampel yang akan diambil.

Sampel yang diambil diberi nomor urut mulai dari nomor satu sampai dengan jumlah sampel terakhir. Pencatatan sampel dilakukan dalam formulir pengambilan data, yang meliputi nama pasien, usia pasien, nomor rekam medik pasien, tanggal resep, nama obat, dosis serta aturan pakai. Rekam medik diambil sesuai dengan nama pasien pada sampel. Data yang dicatat meliputi nama dan umur pasien, nomor rekam medik, diagnosa awal dan akhir. Data yang diperoleh dari rekam medik pasien kemudian dianalisis rasionalitasnya dengan metode Gyssens. Kategori hasil penilaian dengan metode Gyssens adalah sebagai berikut (Ningrum dkk, 2009)

Kategori I : penggunaan antibiotika tepat (rasional)

Kategori IIA : tidak rasional oleh karena dosis yang tidak tepat

Kategori IIB : tidak rasional oleh karena dosis interval yang tidak tepat

Kategori IIC : tidak rasional oleh karena rute pemberian yang salah

Kategori IIIA: tidak rasional oleh karena pemberian antibiotika terlalu lama

Kategori IIIB: tidak rasional oleh karena pemberian antibiotika terlalu singkat 
Kategori IVA: tidak rasional oleh karena ada antibiotika lain yang lebih efektif

Kategori IVB : tidak rasional karena ada antibiotika lain yang kurang toksik

Kategori IVC : tidak rasional karena ada antibiotika lain yang lebih murah

Kategori IVD : tidak rasional karena ada antibiotika lain yang spektrumnya lebih sempit

Kategori V : tidak rasional karena tidak ada indikasi penggunaan antibiotika Kategori VI : data tidak lengkap atau tidak dapat dievaluasi

\section{Analisis Data}

Data yang diperoleh dari rekam medik akan dianalisis rasionalitasnya meliputi ketepatan indikasi, ketepatan obat (jenis antibiotika), ketepatan dosis, ketepatan cara pemberian, ketepatan lama pemberian dan efek samping obat (Oktaviani et al., 2015). Data yang diperoleh kemudian dikategorikan menggunakan metode Gyssen (Gambar 1). Dengan metode ini maka akan didapatkan tingkatan kerasionalitasan pada pemberian antibiotik yang dibagi menjadi 6 kategori dimana evaluasi penggunaan antibiotika sefalosporin dengan metode Gyssen dimulai dari atas yaitu dengan melihat apakah data lengkap atau tidak untuk mengkategorikan penggunaan antibiotika.

1. Bila data tidak lengkap, berhenti di kategori VI dan bila data lengkap maka dilanjutkan ke tahap berikutnya

Dari 100 sampel yang diambil secara simple random sampling (acak) diperoleh ada 10 sampel yang datanya tidak lengkap sehingga 10 sampel tadi berhenti di kategori VI. Data tidak lengkap adalah data rekam medis tanpa diagnosis kerja atau ada halaman rekam medis yang hilang sehingga tidak dapat dievaluasi. Pemeriksaan penunjang/ laboratorium tidak harus dilakukan karena mungkin tidak ada biaya dengan catatan sudah direncanakan pemeriksaannya untuk mendukung diagnosis. Diagnosis kerja dapat ditegakkan secara klinis dari anamnesis dan pemeriksaan fisis. Untuk data yang lengkap (90 sampel) dilanjutkan ke tahap berikutnya yaitu apakah ada infeksi yang membutuhkan antibiotika (antibiotika sesuai indikasi).

2. Bila tidak ada indikasi pemberian antibiotika, berhenti di kategori $V$ dan dari 90 sampel yang bisa dievaluasi ada 89 sampel yang memiliki indikasi yang tepat dan ada 1 sampel yang memiliki indikasi tidak tepat. Untuk antibiotika yang memang memiliki indikasi maka dilanjutkan ke tahap berikutnya yaitu apakah pemilihan antibiotika sudah tepat. 3. Bila ada antibiotika lain yang lebih efektif, berhenti di kategori IVa dan bila tidak maka dilanjutkan ke tahap berikutnya.

Dari 90 sampel yang dievaluasi ada 26 sampel yang mengandung duplikasi antibiotika dikarenakan ada antibiotika yang lebih efektif, sampel sisanya tidak memiliki pilihan antibiotika lain yang lebih efektif sehingga dilanjutkan ke tahap berikutnya yaitu apakah ada alternatif yang kurang toksik.

4. Bila ada pilihan antibiotika lain yang kurang toksik, berhenti di kategori IVb dan bila tidak maka dilanjutkan ke tahap berikutnya

Dari 90 sampel yang dievaluasi tidak ada pilihan antibiotika lain yang kurang toksik selain cefotaxim dan cetriaxon, sehingga pertanyaan di bawahnya dilanjutkan yaitu apakah ada alternatif yang lebih murah.

5. Bila ada pilihan antibiotika lain yang lebih murah, berhenti di kategori IVc dan bila tidak maka dilanjutkan ke tahap berikutnya 
Tidak ada pilihan antibiotika yang lebih murah selain cefotaxim dan ceftriaxon, sehingga pertanyaan di bawahnya dilanjutkan yaitu apakah ada alternatif lain yang spektrumnya sempit.

6. Bila ada pilihan antibiotika lain dengan spektrum yang lebih sempit, berhenti di kategori IVd dan bila tidak maka dilanjutkan ke tahap berikutnya.

Tidak ada pilihan alternatif lain yang spektrumnya lebih sempit, sehingga dilanjutkan ke tahap berikutnya yaitu apakah durasi antibiotika yang diberikan terlalu panjang.

7. Bila durasi pemberian antibiotika terlalu panjang, berhenti di kategori IIIa dan bila tidak maka dilanjutkan ke tahap berikutnya

Durasi pemberian cefotaxim dan ceftriaxon tidak terlalu panjang, sehingga pertanyaan diteruskan yaitu apakah durasi pemberian antibiotika terlalu singkat.

8. Bila durasi pemberian antibiotika terlalu singkat, berhenti di kategori IIIb dan bila tidak maka dilanjutkan ke tahap berikutnya

Durasi pemberian cefotaxim dan ceftriaxon tidak terlalu singkat, sehingga dilanjutkan ke tahap berikutnya yaitu apakah dosis antibiotika yang diberikan sudah tepat.
9. Bila dosis pemberian antibiotika tidak tepat, berhenti di kategori IIa dan bila tepat maka dilanjutkan ke tahap berikutnya

Dari 90 sampel yang dievaluasi ada 76 sampel yang mengandung cefotaxim dengan dosis tepat dan 7 sampel yang mengandung ceftriaxon dengan dosis tepat, sehingga dilanjutkan ke tahap berikutnya yaitu apakah interval antibiotika yang diberikan sudah tepat.

10. Bila interval pemberian antibiotika tidak tepat, berhenti di kategori IIb dan bila tepat maka dilanjutkan ke tahap berikutnya

Interval pemberian sudah tepat, sehingga pertanyaan berikutnya dilanjutkan yaitu apakah rute pemberian antibiotika sudah tepat.

11. Bila rute pemberian antibiotika tidak tepat, berhenti di kategori IIc dan bila tepat maka dilanjutkan ke tahap berikutnya

Rute pemberian antibiotika tepat maka dilanjutkan ke tahap berikutnya berikutnya.

12. Bila antibiotika tidak termasuk kategori I sampai dengan VI, antibiotika tersebut merupakan kategori I. 


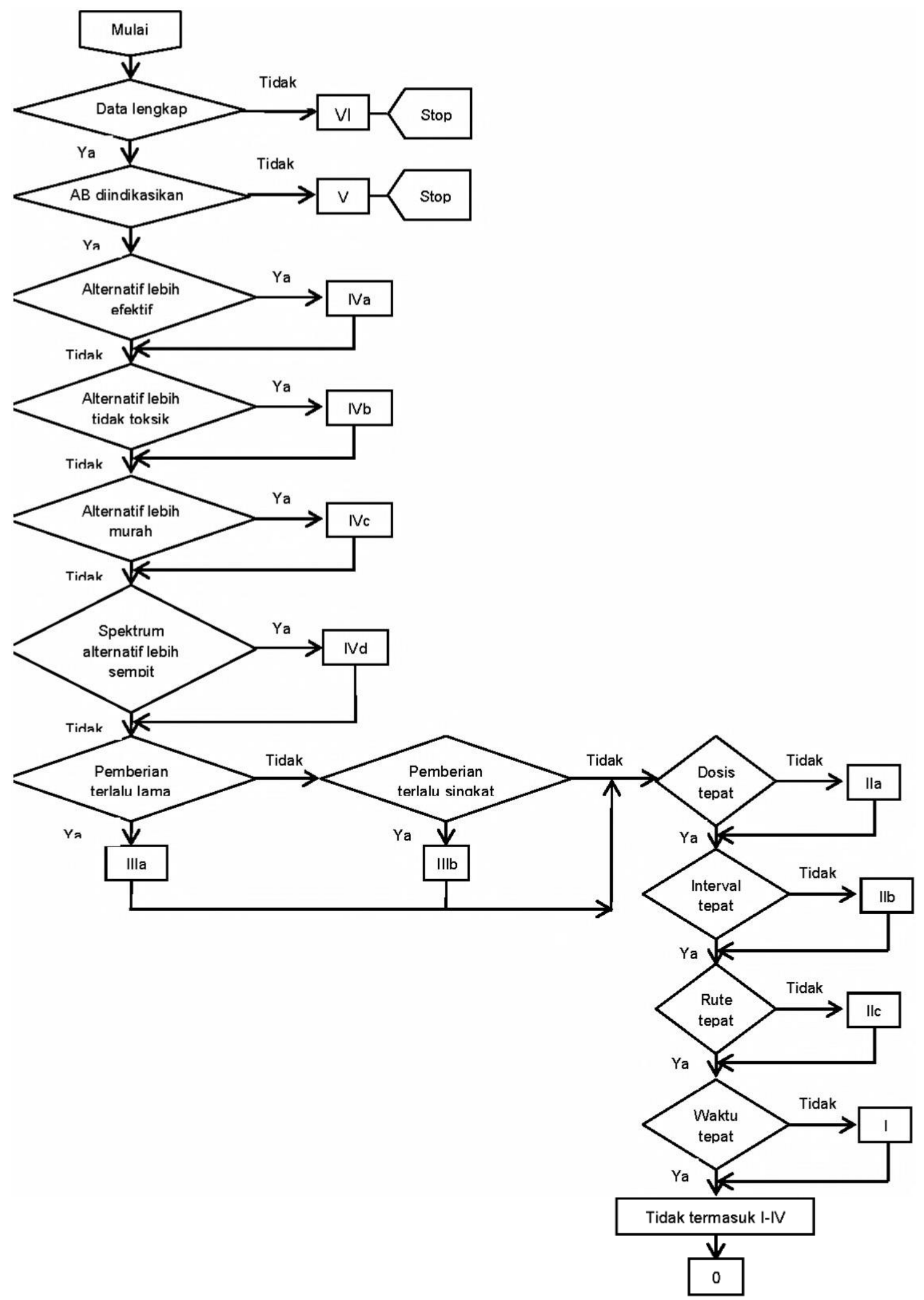

Gambar 1. Penilaian kualitas penggunaan antibiotik (Gyssens flowchart) 


\section{HASIL PENELITIAN \\ Resep}

Data yang diperoleh dari resep adalah nama pasien dan nomor rekam medik pasien, nama obat, dosis, serta aturan pakai obat. Data ini nantinya dievaluasi untuk mendapatkan informasi tentang ketepatan dosis, duplikasi, dan interaksi obat. Di dalam rekam medik itu sendiri diperoleh data umur pasien, riwayat klinik pasien, hasil pemeriksaan pasien seperti hasil laboratorium dan hasil radiologi, dan lain-lain untuk mendapatkan informasi penunjang ketepatan dosis, ketepatan indikasi, dan kontra indikasi. Resep diambil dari seluruh pasien bedah yang ada di RS Dr. H. Marzoeki Mahdi Bogor meliputi jumlah seluruh resep yang mengandung antibiotika sefalosporin selama periode Desember 2011 sampai dengan November 2012 yang ditujukan untuk pasien dewasa maupun anak-anak, berjenis kelamin laki-laki maupun perempuan yang dirawat inap di poliklinik bedah RS Dr H. Marzoeki Mahdi Bogor. Sampel resep diambil secara acak (simple random sampling). Jumlah sampel yang di ambil berjumlah 100 dokumen, yang terdiri dari 53 pasien laki-laki yang meliputi 1 pasien bayi lakilaki, 4 pasien remaja putra, 1 pasien anakanak yang berjenis kelamin laki-laki, dan 47 pasien laki-laki dewasa, sedangkan pasien wanitanya berjumlah 47 orang yang terdiri dari 1 pasien bayi perempuan, 8 pasien remaja putri, dan 38 pasien wanita dewasa. Sampel yang diambil diberi nomor urut mulai dari nomor 1 sampai dengan nomor 100. Dari 100 resep yang diambil secara keseluruhan mengandung antibiotika sefalosporin. Pencatatan dalam formulir pengambilan data meliputi nama dan usia pasien, nomor rekam medik pasien, tanggal resep, diagnosis pasien, nama obat, dosis, dan aturan pakai.

Tabel 1. Form Pengambilan Data Pasien

\begin{tabular}{cllcc}
\hline No & \multicolumn{1}{c}{ Diagnosis Pasien } & $\begin{array}{c}\text { Antibiotika } \\
\text { Sefalosporin Yang } \\
\text { digunakan }\end{array}$ & $\begin{array}{c}\text { Dosis } \\
\text { Obat }\end{array}$ & $\begin{array}{c}\text { Aturan } \\
\text { Pakai } \\
\text { Obat }\end{array}$ \\
\hline 1 & Lipoma Femur Dextra & Cefotaxime injeksi & $1 \mathrm{~g}$ & $2 \mathrm{x} 1$ \\
\hline 2 & Hernia Inguinalis Lateralis Dextra & Cefotaxime injeksi & $1 \mathrm{~g}$ & $2 \mathrm{x} 1$ \\
\hline 3 & Gangren DM & Ceftriaxon injeksi & $2 \mathrm{~g}$ & $2 \mathrm{x} 1$ \\
\hline 4 & Ca Squamosa & Cefotaxime injeks & $1 \mathrm{~g}$ & $3 \mathrm{x} 1$ \\
\hline 5 & Lympadenopati & - & - & - \\
\hline 6 & Tumor Lutra Abdomen & Cefotaxime injeksi & $1 \mathrm{~g}$ & $2 \mathrm{x} 1$ \\
\hline 7 & Hernia Scrotalis Irresponsible & Cefotaxime injeksi & $1 \mathrm{~g}$ & $2 \mathrm{x} 1$ \\
& Dextra & & & \\
\hline 8 & Batu Pyleum & Cefotaxime injeksi & $1 \mathrm{~g}$ & $2 \mathrm{x} 1$ \\
\hline 9 & Hernia Scrotalis Dextra & Cefotaxime injeksi & $1 \mathrm{~g}$ & $2 \mathrm{x} 1$ \\
\hline 10 & BPH & Cefotaxime injeksi & $1 \mathrm{~g}$ & $2 \mathrm{x} 1$ \\
\hline 11 & ISK & Cefotaxime injeksi & $1 \mathrm{~g}$ & $2 \mathrm{x} 1$ \\
\hline 12 & Soft Tissue Punggung & Cefotaxime injeksi & $1 \mathrm{~g}$ & $2 \mathrm{x} 1$ \\
\hline 13 & Carcinoma Papiler Thyroid & Cefotaxime injeksi & $1 \mathrm{~g}$ & $2 \mathrm{x} 1$ \\
\hline 14 & Varises & Cefotaxime injeksi & $1 \mathrm{~g}$ & $2 \mathrm{x} 1$ \\
\hline 15 & Appendicitis Akut & Cefotaxime injeksi & $1 \mathrm{~g}$ & $2 \mathrm{x} 1$ \\
\hline 16 & Appendicitis Akut & Cefotaxime injeksi & $1 \mathrm{~g}$ & $2 \mathrm{x} 1$ \\
\hline 17 & Tumor Parotis Dextra & Cefotaxime injeksi & $1 \mathrm{~g}$ & $2 \mathrm{x} 1$ \\
\hline
\end{tabular}




\begin{tabular}{|c|c|c|c|c|}
\hline No & Diagnosis Pasien & $\begin{array}{c}\text { Antibiotika } \\
\text { Sefalosporin Yang } \\
\text { digunakan }\end{array}$ & $\begin{array}{l}\text { Dosis } \\
\text { Obat }\end{array}$ & $\begin{array}{c}\text { Aturan } \\
\text { Pakai } \\
\text { Obat }\end{array}$ \\
\hline 18 & Tumor Thyroid & Cefotaxime injeksi & $1 \mathrm{~g}$ & $2 \times 1$ \\
\hline 19 & Hernia & Cefotaxime injeksi & $1 \mathrm{~g}$ & $2 \times 1$ \\
\hline 20 & Soft Tissue Tumor & Cefotaxime injeksi & $1 \mathrm{~g}$ & $2 \times 1$ \\
\hline 21 & Tumor Thyroid & Cefotaxime injeksi & $1 \mathrm{~g}$ & $2 \times 1$ \\
\hline 22 & Susp Ca Mammae & - & - & - \\
\hline 23 & Hernia Scrotalis Dextra & Cefotaxime injeksi & $1 \mathrm{~g}$ & $2 \times 1$ \\
\hline 24 & Appendicitis Kronis & Cefotaxime injeksi & $1 \mathrm{~g}$ & $2 \times 1$ \\
\hline 25 & Hernia Inguinal & Cefotaxime injeksi & $1 \mathrm{~g}$ & $2 \times 1$ \\
\hline 26 & Hernia & - & - & - \\
\hline 27 & $\begin{array}{l}\text { Tumor Mammae Dextra (Tumor } \\
\text { Payudara) }\end{array}$ & Cefotaxime injeksi & $1 \mathrm{~g}$ & $2 \times 1$ \\
\hline 28 & Ca Recti & - & - & - \\
\hline 29 & Fistula Perianal & Cefotaxime injeksi & $1 \mathrm{~g}$ & $2 \times 1$ \\
\hline 30 & Fistula Perianal & Cefotaxime injeksi & $1 \mathrm{~g}$ & $2 \times 1$ \\
\hline 31 & Appendicitis Akut & Ceftriaxon injeksi & $1 \mathrm{~g}$ & $2 \times 1$ \\
\hline 32 & Appendicitis & Cefotaxime injeksi & $1 \mathrm{~g}$ & $2 \times 1$ \\
\hline 33 & Appendicitis & Cefotaxime injeksi & $1 \mathrm{~g}$ & $2 \times 1$ \\
\hline 34 & Appendicitis Kronis & Cefotaxime injeksi & $500 \mathrm{mg}$ & $2 \times 1$ \\
\hline 35 & Seminoma & Cefotaxime injeksi & $1 \mathrm{~g}$ & $2 \times 1$ \\
\hline 36 & Appendicitis Kronis & Cefotaxime injeksi & $750 \mathrm{mg}$ & $2 \times 1$ \\
\hline 37 & Haemoroid Grade IV & Cefotaxime injeksi & $1 \mathrm{~g}$ & $2 \times 1$ \\
\hline 38 & Tumor Thyroid & Cefotaxime injeksi & $1 \mathrm{~g}$ & $2 \times 1$ \\
\hline 39 & $\mathrm{BPH}$ & Cefotaxime injeksi & $1 \mathrm{~g}$ & $2 \times 1$ \\
\hline 40 & Hernia Scrotalis Sinistra & Cefotaxime injeksi & $1 \mathrm{~g}$ & $2 \times 1$ \\
\hline 41 & Ca Mammae & Cefotaxime injeksi & $1 \mathrm{~g}$ & $2 \times 1$ \\
\hline 42 & Tumor Payudara Sinistra & Cefotaxime injeksi & $1 \mathrm{~g}$ & $2 \times 1$ \\
\hline 43 & Soft Tissue Axilla Dextra & Cefotaxime injeksi & $1 \mathrm{~g}$ & $2 \times 1$ \\
\hline 44 & Haemoroid & Cefotaxime injeksi & $1 \mathrm{~g}$ & $2 \times 1$ \\
\hline 45 & Appendicitis Akut & Cefotaxime injeksi & $1 \mathrm{~g}$ & $2 \times 1$ \\
\hline 46 & Varises & Cefotaxime injeksi & $1 \mathrm{~g}$ & $2 \times 1$ \\
\hline 47 & Tumor Thyroid & Cefotaxime injeksi & $1 \mathrm{~g}$ & $2 \mathrm{x} 1$ \\
\hline 48 & Soft Tissue Punggung & Cefotaxime injeksi & $1 \mathrm{~g}$ & $2 \times 1$ \\
\hline 49 & Hernia Scrotalis & Cefotaxime injeksi & $1 \mathrm{~g}$ & $2 \times 1$ \\
\hline 50 & Tumor Thyroid & - & - & - \\
\hline 51 & Haemoroid Interna & Cefotaxime injeks & $1 \mathrm{~g}$ & $2 \times 1$ \\
\hline 52 & Hernia Inguinalis Medial & Cefotaxime injeksi & $1 \mathrm{~g}$ & $2 \times 1$ \\
\hline 53 & Basalioma & Cefotaxime injeksi & $1 \mathrm{~g}$ & $2 \times 1$ \\
\hline 54 & Hernia Inguinalis Bilateral & Cefotaxime injeksi & $1 \mathrm{~g}$ & $2 \times 1$ \\
\hline 55 & Hernia & Cefotaxime injeksi & $1 \mathrm{~g}$ & $2 \times 1$ \\
\hline 56 & Soft Tissue & Cefotaxime injeksi & $1 \mathrm{~g}$ & $2 \times 1$ \\
\hline 57 & Appendicitis Kronis & Ceftriaxon injeksi & $2 \mathrm{~g}$ & $1 \mathrm{x} 1$ \\
\hline 58 & Anemia Gravis dengan Haemoroid & Cefotaxime injeksi & $1 \mathrm{~g}$ & $2 \times 1$ \\
\hline 59 & Appendicitis Akut & Cefotaxime injeksi & $1 \mathrm{~g}$ & $2 \times 1$ \\
\hline 60 & Tumor Mammae Dextra & Cefotaxime injeksi & $1 \mathrm{~g}$ & $2 \times 1$ \\
\hline 61 & Tumor Intra Abdomen & Cefotaxime injeksi & $1 \mathrm{~g}$ & $2 \times 1$ \\
\hline 62 & Hernia Inguinalis Lateral Sinistra & Cefotaxime injeksi & $1 \mathrm{~g}$ & $2 \times 1$ \\
\hline
\end{tabular}




\begin{tabular}{|c|c|c|c|c|}
\hline No & Diagnosis Pasien & $\begin{array}{c}\text { Antibiotika } \\
\text { Sefalosporin Yang } \\
\text { digunakan }\end{array}$ & $\begin{array}{l}\text { Dosis } \\
\text { Obat }\end{array}$ & $\begin{array}{c}\text { Aturan } \\
\text { Pakai } \\
\text { Obat }\end{array}$ \\
\hline 63 & Konstipasi & Cefotaxime injeksi & $1 \mathrm{~g}$ & $2 \times 1$ \\
\hline 64 & Appendicitis & Cefotaxime injeksi & $1 \mathrm{~g}$ & $2 \times 1$ \\
\hline 65 & Hernia Scrotalis Dextra & Cefotaxime injeksi & $1 \mathrm{~g}$ & $2 \times 1$ \\
\hline 66 & Tumor Parotitis & Cefotaxime injeksi & $1 \mathrm{~g}$ & $2 \times 1$ \\
\hline 67 & Tumor Thyroid & - & - & - \\
\hline 68 & Haemoroid & Cefotaxime injeksi & $1 \mathrm{~g}$ & $2 \times 1$ \\
\hline 69 & Tumor Thyroid & Cefotaxime injeksi & $1 \mathrm{~g}$ & $2 \times 1$ \\
\hline 70 & Tumor Mamma Sinistra & Cefotaxime injeksi & $1 \mathrm{~g}$ & $2 \times 1$ \\
\hline 71 & Appendicitis & Cefotaxime injeksi & $1 \mathrm{~g}$ & $2 \times 1$ \\
\hline 72 & Hernia Scrotalis Sinistra & Cefotaxime injeksi & $1 \mathrm{~g}$ & $2 \times 1$ \\
\hline 73 & Osteomylitis Pedis & Ceftriaxon injeksi & $1 \mathrm{~g}$ & $2 \times 1$ \\
\hline 74 & - & $\begin{array}{l}\text { Ceftazidine injeksi } \\
\text { Cefotaxime injeksi }\end{array}$ & $\begin{array}{l}500 \mathrm{mg} \\
500 \mathrm{mg}\end{array}$ & $\begin{array}{l}2 \times 1 \\
3 \times 1\end{array}$ \\
\hline 75 & $\begin{array}{llll}\begin{array}{l}\text { Fr. Vertebrae } \\
\text { Spondilitis }\end{array} & \text { Lumbal } & \text { I } & \mathrm{dg} \\
\end{array}$ & Cefotaxime injeksi & $1 \mathrm{~g}$ & $2 \times 1$ \\
\hline 76 & Tumor Thyroid & - & - & - \\
\hline 77 & Kolik Abdomen & Ceftriaxon injeksi & $1 \mathrm{~g}$ & $2 \times 1$ \\
\hline 78 & Haemoroid Interna Grade II & - & - & - \\
\hline 79 & Hernia Inguinalis & Cefotaxime injeksi & $1 \mathrm{~g}$ & $2 \times 1$ \\
\hline 80 & Hernia & Cefotaxime injeksi & $1 \mathrm{~g}$ & $2 \mathrm{x} 1$ \\
\hline 81 & Hernia & Cefotaxime injeksi & $1 \mathrm{~g}$ & $2 \times 1$ \\
\hline 82 & $\mathrm{BPH}$ & Cefotaxime injeksi & $1 \mathrm{~g}$ & $2 \times 1$ \\
\hline 83 & Hernia Scrotalis & Cefotaxime injeksi & $1 \mathrm{~g}$ & $2 \times 1$ \\
\hline 84 & Soft Tissue & Cefotaxime injeksi & $1 \mathrm{~g}$ & $2 \times 1$ \\
\hline 85 & Tumor Thyroid & - & - & - \\
\hline 86 & Hernia Ingunalis Lateral Dextra & Cefotaxime injeksi & $1 \mathrm{~g}$ & $2 \times 1$ \\
\hline 87 & Hernia Scrotalis & - & - & - \\
\hline 88 & Cholelithiasis & Cefotaxime injeksi & $1 \mathrm{~g}$ & $2 \times 1$ \\
\hline 89 & Tumor Mammae Kanan & Ceftriaxon inj & $1 \mathrm{~g}$ & $2 \times 1$ \\
\hline 90 & Appendicitis & Lapixime injeksi & $1 \mathrm{~g}$ & $2 \times 1$ \\
\hline 91 & Tumor di bibir atas & Cefotaxime injeksi & $1 \mathrm{~g}$ & $2 \times 1$ \\
\hline 92 & Tumor Parotis & Cefotaxime injeksi & $1 \mathrm{~g}$ & $2 \times 1$ \\
\hline 93 & Hernia Scrotalis Sinistra & Cefotaxime injeksi & $1 \mathrm{~g}$ & $2 \times 1$ \\
\hline \multirow[t]{2}{*}{94} & Appendicitis & Ceftriaxone injeksi & $1 \mathrm{~g}$ & $2 \times 1$ \\
\hline & & Cefotaxime injeksi & $1 \mathrm{~g}$ & $2 \times 1$ \\
\hline 95 & Tumor Soft Tissue & Cefotaxime injeksi & $1 \mathrm{~g}$ & $2 \times 1$ \\
\hline 96 & Batu Pyelum & Cefotaxime injeksi & $1 \mathrm{~g}$ & $2 \times 1$ \\
\hline 97 & Appendicitis & Cefotaxime injeksi & $750 \mathrm{mg}$ & $2 \times 1$ \\
\hline 98 & Appendicitis kronis & Cefotaxime injeksi & $1 \mathrm{~g}$ & $2 \times 1$ \\
\hline 99 & Appendicitis & Terpacef injeksi & $100 \mathrm{mg}$ & $2 \times 1$ \\
\hline 100 & Hernia Inguinalis Dextra & Cefotaxime injeksi & $1 \mathrm{~g}$ & $2 \times 1$ \\
\hline
\end{tabular}

Hasil tabel observasi dari sampel yang ditemukan tampak pada Tabel 1 yaitu diperoleh data jenis cephalosporin yang diresepkan dokter adalah cefotaxim sebanyak 80 lembar, ceftriaxon sebanyak 8 lembar, dan ceftazidin sebanyak 1 
lembar, dan cefixime sebanyak 1 lembar. Dari 100 sampel resep yang diambil diperoleh data yaitu ada 10 sampel resep yang tidak tepat karena tidak mengandung antibiotika cephalosporin dan tidak mencantumkan dosis serta aturan pakai obat. Untuk setiap data pasien, dilakukan penilaian berdasarkan alur Gyssen. Hasil penilaian dari 100 sampel resep yang diambil adalah ada 10 sampel resep yang tidak tepat (kategori VI) sehingga data tidak dapat dievaluasi. Resep dikatakan tepat bila di dalamnya mengandung kriteria inklusi

\section{Ketepatan Dosis}

Dosis cefotaxim pada bayi dan anak usia 1-12 tahun atau berat badan kurang dari $50 \mathrm{~kg}$ untuk pemberian im dan iv adalah $50-200 \mathrm{mg} / \mathrm{kg} \mathrm{BB} /$ hari setiap 6-8 jam. Pada anak di atas 12 tahun dan dewasa maka pemberian im dan iv adalah 1-2 gram tiap 4-12 jam. Pasien gangguan ginjal dengan klirens kreatinin kurang dari $10 \mathrm{ml} /$ menit maka sefotaksim diberikan tiap 24 jam. Dosis cefotaxim pada infeksi sedang sampai berat yaitu 1-2 gram setiap 6-8 jam. Untuk infeksi berat atau membahayakan diperlukan 2 gram setiap 4 jam, sedangkan untuk pencegahan infeksi yang terjadi setelah operasi yaitu 1 gram im atau iv 30-90 menit sebelum pembedahan. Pada kasus operasi cesar, dosis cefotaxim sebesar 1 gram iv setelah umbilical cord diklem kemudian 1 gram im atau iv yaitu 6 dan 12 jam setelah dosis pertama. Dosis maksimal yang dianjurkan adalah 12 gram per hari.

Ekskresi cefotaxim melalui ginjal, sehingga pada pasien gagal ginjal akan mengalami hambatan ekskresi. Karena alasan itulah, perlu dilakukan penyesuaian dosis supaya tidak terjadi peningkatan kadar obat dalam plasma dan pembebanan ginjal. Dosis yang dianjurkan adalah 3-4 gram dalam dekstrosa 100 cc diberikan selama setengah jam per infus sekali sehari diberikan 3 hingga 5 hari.

Terdapat 79 resep yang mengandung cefotaxim yang dosisnya tepat dan 3 resep yang dosisnya tidak tepat. Ketidaktepatan dosis terletak pada interval pemberiannya. Berdasarkan metode Gyssen maka diperoleh ada 3 terapi antibiotika cephalosporin yang termasuk kategori II A yaitu resep tidak rasional karena dosis tidak tepat.

Tabel 2. Ketepatan Dosis

\begin{tabular}{lcccc}
\hline $\begin{array}{c}\text { Jenis } \\
\text { cephalosporin }\end{array}$ & $\begin{array}{c}\text { Jumlah Dosis } \\
\text { Tepat (lembar) }\end{array}$ & $\begin{array}{c}\text { Prosentase } \\
(\boldsymbol{\%})\end{array}$ & $\begin{array}{c}\text { Jumlah Dosis Tidak } \\
\text { Tepat (lembar) }\end{array}$ & $\begin{array}{c}\text { Prosentase } \\
(\boldsymbol{\%})\end{array}$ \\
\hline cefotaxim & 79 & 92,94 & 3 & 75 \\
\hline ceftriaxon & 5 & 5,88 & 1 & 25 \\
\hline ceptazidin & 1 & 1,18 & 0 & 0 \\
\hline Jumlah & 85 & 100,00 & 4 & 100 \\
\hline
\end{tabular}

\section{Ketepatan Indikasi}

Tindakan bedah mempunyai resiko terjadinya infeksi di tempat pembedahan. Resiko yang terjadi tergantung dari kondisi pasien dan pelaksanaan pembedahan. Pemberian antibiotika profilaksis bedah dapat menghambat pertumbuhan bakteri kontaminan, sehingga bisa menurunkan resiko terjadinya infeksi di tempat pembedahan. Antibiotika yang direkomendasikan untuk profilaksis bedah adalah antibiotika beta laktam dengan merekomendasikan antibiotika 
lain sebagai alternatif untuk pasien yang alergi terhadap penisilin dan sefalosporin.

Penggunaan cephalosporin di ruang rawat inap pasien bedah dimaksudkan untuk profilaksis bedah. Seluruh resep memiliki indikasi yang tepat karena semua pasien yang resepnya diambil sebagai sampel mengalami tindakan pembedahan.

Adapun infeksi yang sensitif terhadap cefotaxim antara lain infeksi saluran nafas bagian bawah (termasuk pneumonia), infeksi kulit dan struktur kulit, infeksi tulang dan sendi, infeksi saluran kemih, infeksi pada alat kelamin wanita, meningitis, septikemia, dan bakteremia. Cefotaxim tidak efektif terhadap triponemapalidum dan clostridium difficile. Cefotaxim aktif terhadap bakteri gram negatif seperti E. coli, klebsiella sp, proteus sp, serratia sp, neisseria $\mathrm{sp}$, bacteriodes $\mathrm{sp}$ dan bakteri gram positif seperti staphylococci, streptococci aerob dan anaerob, streptococcus pneumoniae, clostridium sp.

Penggunaan cephalosporin di ruang rawat inap pasien bedah dimaksudkan untuk profilaksis bedah. Hampir seluruh resep (89) memiliki indikasi yang tepat, karena hampir semua pasien mengalami tindakan pembedahan, sisanya dari 100 resep yang dijadikan sampel ada 11 resep yang datanya tidak lengkap dan pembedahannya tidak menggunakan antibiotika. Berdasarkan metode Gyssen maka dari 100 terapi antibiotika sefalosporin yang termasuk kategori I memenuhi konsep rasional sebesar 89 terapi antibiotika cephalosporin, sedangkan yang termasuk kategori $\mathrm{V}$ ada 11 terapi antibiotika cephalosporin yang tidak sesuai indikasinya.

Tabel 3. Ketepatan Indikasi

\begin{tabular}{lcccc}
\hline $\begin{array}{c}\text { Jenis } \\
\text { cephalosporin }\end{array}$ & $\begin{array}{c}\text { Jumlah Indikasi } \\
\text { Tepat (lembar) }\end{array}$ & $\begin{array}{c}\text { Prosentase } \\
(\%)\end{array}$ & $\begin{array}{c}\text { Jumlah Indikasi Tidak } \\
\text { Tepat (lembar) }\end{array}$ & $\begin{array}{c}\text { Prosentase } \\
(\%)\end{array}$ \\
\hline cefotaxim & 82 & 92,13 & 0 & 0,00 \\
\hline ceftriaxon & 6 & 6,74 & 0 & 0,00 \\
\hline ceptazidin & 1 & 1,12 & 0 & 0,00 \\
\hline Jumlah & 89 & 99,99 & 0 & 0,00 \\
\hline
\end{tabular}

\section{Kontra Indikasi}

Kontra indikasi pemakaian obat antibiotika cephalosporin untuk pasien anak dan dewasa adalah hipersensitif cephalosporin. Kebanyakan reaksi hipersensitivitas sistemik yang paling serius disebabkan oleh cephalosporin. Resiko berupa reaksi anafilaksis terjadi pada 1:1000 sampai 1:1.000.000. Faktor resiko akan meningkat 4 kalinya pada pasien dengan riwayat alergi penisilin. Kejadian reaksi silang alergi cephalosporin pada pasien dengan alergi penisilin dilaporkan antara $7 \%-18 \%$. Pasien yang dijadikan sampel penelitian mendapatkan antibiotika cephalosporin selama lebih dari satu hari. Reaksi hipersensitivitas seringkali muncul segera atau beberapa saat setelah pemberian obat, sehingga dokter akan menghentikan antibiotika atau mengganti dengan antibiotika alternatif. Selain itu, cefotaxim dikontraindikasikan pada pasien yang memiliki masalah ginjal yang berat.

Pada rekam medik pasien tidak ditemukan adanya diagnosa tambahan adanya hipersensitivitas pasien. Berdasarkan hal tersebut dapat disimpulkan penggunaan antibiotika 
cephalosporin tersebut tidak ada kontra indikasinya. Berdasarkan kriteria Gyssen termasuk dalam kategori I yaitu memenuhi konsep rasional.

Tabel 4. Kontra Indikasi

\begin{tabular}{lcccc}
\hline $\begin{array}{c}\text { Jenis } \\
\text { cephalosporin }\end{array}$ & $\begin{array}{c}\text { Jumlah Ada } \\
\text { Kontra } \\
\text { Indikasi }\end{array}$ & Prosentase (\%) & $\begin{array}{c}\text { Jumlah Tanpa } \\
\text { Kontra } \\
\text { Indikasi }\end{array}$ & $\begin{array}{c}\text { Prosentase } \\
(\boldsymbol{\%})\end{array}$ \\
\hline cefotaxim & 82 & 92,13 & 0 & 0,00 \\
\hline ceftriaxon & 6 & 6,74 & 0 & 0,00 \\
\hline ceptazidin & 1 & 1,12 & 0 & 0,00 \\
\hline Jumlah & 89 & 99,99 & 0 & 0,00 \\
\hline
\end{tabular}

\section{Duplikasi Antibiotika}

Studi ini menunjukkan bahwa jumlah duplikasi antibiotika sebanyak 26 lembar $(29,55 \%)$, sedangkan resep yang tidak ada duplikasinya sebanyak 62 lembar $(70,45 \%)$. Penggunaan kombinasi dari dua atau lebih antibiotika tidak dianjurkan, apalagi kombinasi dengan dosis tetap. Duplikasi antibiotika yang tidak tetap justru memberikan dampak negatif pada pasien, diantaranya menyebabkan terjadinya resistensi, memperberat efek samping atau meningkatnya biaya untuk membeli obat (Utami, 2011).

Pada infeksi parah dimana jiwa pasien terancam,maka kombinasi cefotaxim dengan aminoglikosida dapat diberikan tanpa menunggu hasil tes sensitivitas. Kedua sediaan tersebut harus diberikan secara terpisah, tidak dicampur dalam satu syringe.

Menurut Cunha (2001), penggunaan kombinasi antibiotika yang tepat harus dapat mencapai sasaran sebagai berikut:

1. Kombinasi bekerja sinergik terhadap mikroorganisme penyebab infeksi.

2. Kombinasi mencegah terjadi resistensi mikroorganisme.

3. Kombinasi sebagai tindak awal penanganan infeksi yang disebabkan oleh beberapa mikroorganisme.

4. Kombinasi digunakan untuk menangani beberapa infeksi sekaligus.

Tabel 5. Duplikasi Antibiotika

\begin{tabular}{ccccc}
\hline Jenis Duplikasi & $\begin{array}{c}\text { Ada } \\
\text { Duplikasi } \\
\text { (lembar) }\end{array}$ & $\begin{array}{c}\text { Prosentase } \\
(\%)\end{array}$ & $\begin{array}{c}\text { Tidak Ada } \\
\text { Duplikasi } \\
\text { (lembar) }\end{array}$ & $\begin{array}{c}\text { Prosentase } \\
(\%)\end{array}$ \\
\hline Cefotaxim-Amoxicillin & 17 & 65,38 & & \\
\hline Cefotaxim-Ciprofloxacin & 4 & 15,38 & & \\
\hline Cefotaxim-Ceptazidin & 1 & 3,85 & 62 & \\
\hline Cefotaxim-Streptomycin & 1 & 3,85 & & \\
\hline Cefotaxim-Ceptriaxon & 1 & 3,85 & & 100 \\
\hline Cefotaxim-Erythromicin & 2 & 7,69 & & \\
\hline Jumlah & 26 & 100 & 62 & \\
\hline
\end{tabular}

\section{KESIMPULAN}

Berdasarkan hasil evaluasi peresepan antibiotika cephalosporin menggunakan metode Gyssens yang ditujukan pada pasien bedah RS Dr. $\mathrm{H}$. Marzoeki Mahdi Bogor diperoleh dari 
100 terapi antibiotika cephalosporin, sebanyak 2 terapi termasuk kategori VI (data tidak lengkap), 3 terapi termasuk kategori II A (dosis tidak tepat), 11 terapi termasuk kategori $\mathrm{V}$ (tidak sesuai indikasinya) dan sebanyak 89 terapi termasuk kategori I (memenuhi konsep rasional). Rasionalitas antibiotika pada rekam medis pasien bedah menunjukkan bahwa sebagian besar antibiotika cephalosporin yang digunakan berada di kategori I. Hanya sebagian kecil saja penggunaan antibiotika cephalosporin yang memenuhi kategori VI.

\section{REFERENSI}

Cunha, B. A. 2001. Antibiotic side effect. Med. Clin. North Am. 85(1): 149185.

Dellinger, E., Gross, P., Barret, T.L, Krause, T.J., Martone, W.J. et al. 1994. Quality standard of antimicrobial prophylaxis in surgical procedure. Clin. Infect. Dis.18(3): 422-427.

Oktaviani, F., Wahyono, Dj. \& Yuniarti, E. 2015. evaluasi penggunaan antibiotik profilaksis terhadap kejadian infeksi luka operasi pada operasi sectio caesarea. Jurnal Manajemen dan Pelayanan Farmasi. 5(4): 255-258.
Kusuma-Ningrum, T.I., Nugroho, T.L. \& Lestari E.S. 2009. Evaluasi antibiotika berdasarkan kriteria Gyssens pasien rawat inap kelas III di bagian ilmu penyakit dalam RSUP Dr. Kariadi periode Agustus s/d Desember 2008. Artikel Penelitian Karya Tulis Ilmiah. Repositori Fakultas Kedokteran. Universitas Diponegoro.

Linda, T. 2004. Panduan Pencegahan Infeksi Untuk Fasilitas Pelayanan Kesehatan Dengan Sumber Daya Terbatas. Yayasan Bina Pustaka Sarwono Prawirohardjo. Semarang.

Riduwan, R., 2012. Skala Pengukuran Variable-variabel. Cetakan 12. Penelitian. C.V Alfabeta. Bandung.

Siregar, C.J.P. 2013. Farmasi Klinik: Teori \& Penerapan. Penerbit EGC. Jakarta.

Utami, E.R., 2011. Antibiotika, resistensi, dan rasionalitas terapi. $E l$ Hidayah Jurnal Biologi. 1(4): 192-198.

Widodo, Dj., 2006, Demam Tifoid, Ilmu Penyakit Dalam. Edisi IV, Fakultas Kedokteran Universitas Indonesia. Jakarta. 